\title{
Art of Bangladesh: the Changing Role of Tradition, Search for Identity and Globalization
}

Lala Rukh Selim

\section{(2) OpenEdition}

\section{Journals}

\section{Electronic version}

URL: https://journals.openedition.org/samaj/3725

DOI: $10.4000 /$ samaj.3725

ISSN: $1960-6060$

\section{Publisher}

Association pour la recherche sur l'Asie du Sud (ARAS)

\section{Electronic reference}

Lala Rukh Selim, "Art of Bangladesh: the Changing Role of Tradition, Search for Identity and Globalization", South Asia Multidisciplinary Academic Journal [Online], 9 | 2014, Online since 22 July 2014, connection on 21 September 2021. URL: http://journals.openedition.org/samaj/3725 ; DOI: https://doi.org/10.4000/samaj.3725

\section{This text was automatically generated on 21 September 2021.}

\section{c)}

This work is licensed under a Creative Commons Attribution-NonCommercial-NoDerivatives 4.0 International License. 


\title{
Art of Bangladesh: the Changing Role of Tradition, Search for Identity and Globalization
}

\author{
Lala Rukh Selim
}

\section{Introduction}

1 The art of Bangladesh embodies the social and political changes that have transformed the country/region through history. What was once a united state of Bengal is now divided into two parts, the sovereign country of Bangladesh and the state of West Bengal in India. The predominant religion in Bangladesh is Islam and that of West Bengal is Hinduism. Throughout history, ideas and identifications of certain elements of culture as 'tradition' have played an important role in the construction of notions of identity in this region, where multiple cultures continue to meet. The celebrated pedagogue, writer and artist K. G. Subramanyan (1987: 7) terms as 'tradition' the continuity structure into which each man is born. Geeta Kapur (2000) opines that 'tradition' and 'modernity' in third world debates serve as symbols within the cultural disputes of decolonization. The term tradition, as used to refer to India and the third world, is not a disinterested legacy. In India (and Bangladesh) in recent years the term was brought into play in the struggle by nineteenth century nationalism and used in the process of decolonization to embody the power of resistance as an oppositional category. Thus, Kapur (2000: 267-268) suggests, tradition is empowered to transform routinely transmitted materials from the past into charged forms that can claim contemporary and radical effect. In this sense, the concept of tradition is inseparable from the idea and experience of modernity. This view is distinct from the more usual outlook in which tradition and modernity are opposed, and it also ties both concepts into a postmodern framework and places them within the political context of the modern nation-state. In other words, modernity itself promotes tradition and tradition does not exist outside of modernity (Thompson 2006: 3-4). The impact of the politics of identity formed through the selection and invention of tradition is evident in the art of Bangladesh. Identities have been formed mostly in the face of 
political, economic and cultural challenges (Gupta \& Ferguson 1992: 8), and in the current postmodern state, globalization has affected a transnational public sphere where the concept of locality has changed. Identity is not bound to space as it was in the modern era. The politics of identity, solidarity and cultural difference thus have to be rethought (Gupta \& Ferguson 1992: 9). This reconceptualization of space also affects the art of Bangladesh. Within this new context the resolution of identity becomes more problematic. The past practice of facile adoption of traditional signifiers no longer holds. National issues no longer figure only in the national context or for a national viewership; they are presented on a global platform. The language and concerns that dominate the global art scene and the legibility of the artwork are important considerations for artists for whom the global art world has become more accessible. International political, economic, environmental and social concerns intimately connect the globalized world and come to feature in the works of Bangladeshi artists. 'Traditions' are brought into use more as marks of identification than as politically charged symbols, subtly inflected for the global art world which is eager to promote pluralism and difference.

2 Historically, the society, culture and art of Bengal have been syncretic, bringing together ideas that seem irreconcilable while their aesthetic manifestations have retained identifiable local characteristics. Over the last two millennia Buddhism, Jainism, Hinduism, Islam and Christianity have been practised in Bengal and many different peoples have contributed to the area's complex aesthetic heritage. The synthesis of these different influences has contributed to the hybrid culture of Bengal (Blurton 2006: 7-19, Roy 1993: 477-478, Eaton 1984: 23-36, Haque 1980: 1-14, Skelton 1979: 15-21). Artists have drawn on different aspects of traditions at different times in attempts to reflect and create new identities (Rushdie 1991: 67-68). Identity and nationalism are charged issues in the colonial and post-colonial society of Bangladesh. Currently the 'contemporary' in art and 'globalization' has come to feature in the discourse of the Bangladesh art world as it reaches out to the global sphere. This paper describes these changes through time.

\section{Art of Bengal under British rule}

By the time the subcontinent became part of the British Empire, traditional arts ${ }^{1}$ had lost the appreciation of the local intelligentsia (Guha-Thakurta 2007: 147-153). Western art had first made its way into the Mughal court in the sixteenth century, and by the next century painters were incorporating elements from Mannerist art. But the ambitious art policy of the British Raj had much to do with the rapid spread of academic art in colonial India (Mitter 1994: 12, Narzary 1993: 44-47). According to Mitter, '[...] its [European art's] introduction to the Raj was part of a comprehensive package that sought to reproduce the cultural values of the West' (Mitter 1994: 12). The British established art schools to train drawing masters, draftsmen, modellers, surveyors and engravers; providing new kinds of vocational training (Guha-Thakurta 2007: 143, Mitter 1994: 30-31).

An art school was founded in Kolkata in 1854 with this goal in view. Elite dominance was pronounced at the school, where the majority of the students belonged to the bhadralok (gentry) castes, though some students from the hereditary artist castes did initially join (Mitter 1994: 55). This and other art schools were established on the model of the Central School of Industrial Art at South Kensington to teach 'applied art' and not 'fine art' as imparted by the Royal Academy. There were ingrained anomalies in the syllabus due to confusion in Britain itself regarding art education, particularly in the policy for India. The 
enthusiasm for academic naturalism amongst teachers and pupils, and the taste for academic art, which had gradually grown in the subcontinent, transformed the art schools into academies (Mitter 1994: 29-60). Because English education flourished in Kolkata, those who most profited from the new opportunities provided by art education were the intelligentsia. Hardly any decorative artists graduated while there were many academic ones (Mitter 1994: 55). The concept of the artist as an individual, as opposed to a link in a chain of unbroken traditions, was also created during the colonial era (Mitter 1994: 13).

5 With the rise of nationalism in Bengal came an assertion of ownership and authority over Indian art in opposition to the construction of Western scholars. This authority claimed that Indian traditions could be best understood by Indians. The proponents situated themselves within a dominant Western field of practice and knowledge, of art and art history, demarcating a separate space from which the authors addressed a Bengali readership and proffered an 'indigenous' point of view. The first such Bengali text on Indian art history is Shyamacharan Srimani's Suksa Shilper Utpatti o Aryajatir Shilpa-chaturi [The Rise of the Fine Arts and the Artistic Skills of the Aryans] (1874) (Guha-Thakurta 2007: 140-152). In the 1900s a new group of orientalist writers set out to re-appropriate the study of Indian art from earlier Western scholarship, 'to recover its 'true' and 'authentic' history.' Nationalist thought was based on the central divide between the material achievements of the West and the spiritual/transcendental wisdom of the East, a heuristic distinction most powerfully invoked in the nation's art (Guha-Thakurta 2007: 155). This saw the growth of the Bengal School, under the guidance of Abanindranath Tagore, which produced modern 'Indian style' paintings, stamped with the romantic idealistic values that the orientalists recognized as the essence of ancient Indian art (Guha-Thakurta 2007: 158). Their challenge to Western mimesis would 'exercise a very far-reaching influence on the future of Indian art' (Mitter 1994: 309).

6 Indian art history, as formulated by Western scholars and taken up by local scholars, looked to an ancient classical past for its roots and nourishment. The art produced locally in the present seemed crude and naïve to a colonized intelligentsia steeped in ideas of India's glorious past and their desire to match westernized models of artistic refinement. Only the Hindu period of Indian history was considered of consequence by Abanindranath, though Mughal, Pahari and provincial miniature paintings were central to the style of the Bengal School. ${ }^{2}$ The secular court painting traditions of these schools were accommodated within a hieratic pattern of art history that placed the religious over the secular. Abanindranath's construct of the 'idealistic' character of Indian art was such that the secular court painting traditions of Mughal or Pahari schools could not be placed on the same level as the religious genres of Buddhist and Hindu art (Guha-Thakurta 2007: 165). A nationalist image of a 'homogenous Hindu past' was by implication exclusive because in India, with its diverse mix of classes, languages, religions, and regions, no community can claim an exclusive inheritance. In Bengal, the population had absorbed many Muslim social and cultural practices during long periods of Muslim rule (Mitter 1994: 236-239). ${ }^{3}$

7 By the time of the partition of India in 1947 the spiritualism of the Bengal School had lost its grip. The social and political movements of the 1940s inspired a sense of social responsibility in artists from which, according to some art theorists, grew the first modern trends in art (Hossain 2007: 301). Artists were struggling to reconcile local context and identify and insert what they imagined as traditions within the aesthetic 
framework of Western ideas and a plethora of Western art movements to which they were exposed (Bhattacharya 1994: 209-226).

\section{Partition, the Language Movement and the art establishment}

The independence of the subcontinent from British rule in 1947 was followed by the partition of the country into two separate states, India and Pakistan, based on the Two Nation Theory (Rashid 2007: 76). Bengal was divided and its eastern part became East Pakistan which, together with West Pakistan, many hundreds of miles to the west, constituted a separate homeland for Muslims. West Bengal became a state of the Indian federation. Due to the geographical distance between the two halves of Pakistan and differences in culture, the literature and arts of East Pakistan developed independently. The discriminatory and inequitable attitude of the Pakistani rulers led to the beginning of the struggle for political and cultural rights almost simultaneously with the birth of Pakistan. Thus, the inhabitants of East Pakistan attempted to embody what was imagined as indigenous traditions in the arts in resistance to the communal cultural concept of Pakistan as a state based on religion (Mansur 2007: 39).

Several of the Muslim teachers of the Calcutta Art School opted to move to East Pakistan. Among them Zainul Abedin (1914-1976) and Safiuddin Ahmed (1922-2012) were already recognized artists in India. A university had already been established in Dhaka (in 1921) in the interest of the people of this region: this created an environment for education and cultural growth (Hossain 2007: 302). Quamrul Hassan (1921-1988), who had been a student of the Calcutta Art School, also moved to Dhaka in 1948. The presence of these three in Dhaka, the capital of East Pakistan, led to the founding of an art institute in Dhaka in 1948. The excitement of a new nation again called forth the spirit of nationalism and the need for building a separate Pakistani 'identity' for the nation from the undivided past. Thus, the first exhibition, organized to encourage the Pakistani rulers to establish an art school in Dhaka, was a series of posters portraying the conquest of India by Muslims and the birth of Pakistan, held on 14 August 1948, Pakistan Day (Selim 1998: 7). It was an attempt to establish a Muslim identity to bridge the vast geographical and cultural divide that separated East and West Pakistan. The strategy was successful and an art institute was established in Dhaka along the lines of the Calcutta Art School, where the entire founding faculty had been teachers. Institution building was an important activity as Dhaka had no art schools, galleries or viewers (Islam 2000: 16).

The euphoria of independence had hardly subsided when the Language Movement began in East Pakistan. There were many dissenting ideas prior to Partition about the identity of the Bengali Muslim (Anisuzzaman 1993: 91-96). The Pakistan government pronounced in 1948 that Urdu would be the only state language of Pakistan despite the fact that the majority of the population was Bengali speaking. This shattered the vision of a unified Pakistan for the Bengalis. The Language Movement brought the language and cultural heritage of the Bengali people to the forefront and led to the realization that religion could not supplant culture (Umar 1967: 1-12). An inclusive, common, secular Bengali culture was imagined by Bengalis struggling for their language and cultural autonomy, ultimately leading to conceptualizing the nation state. As Abdul Huq ${ }^{4}$ notes: 'The combination of the Muslim culture and the culture of the minorities constitute the total 
culture of East Pakistan...' and 'The culture we shall develop will be based on our nationhood; its religious characteristics may not become dominant' (Anisuzzaman 1993: 104).

In 1952 people died for the Language Movement, which gradually expanded to become the movement for autonomy and finally, for liberation. West Pakistan had supplanted the British as colonial oppressors and resistance became a powerful unifying force for Bengalis and other groups that occupied the former East Pakistan. Artists were integrated into the slowly expanding group of intelligentsia of Dhaka and became vocal against the injustices of Pakistani rulers. This was perhaps the beginning of the long involvement of artists with political struggles in Bangladesh.

\section{The growth of an art movement}

Against this backdrop, Zainul Abedin, Safiuddin Ahmed, Quamrul Hassan, and S. M. Sultan (1923-1994), became the mainstay of the art movement which began to develop in what was then East Pakistan. Their art addressed the environment and society within which they were situated. They did not merely adopt the formal language of modernism but made a contextual use of modern language. To borrow from R. Siva Kumar (2002: 9) when he speaks of Abanindranath Tagore, Nandalal Bose and K. G. Subramanyan:

They understood modernism not as a stylistic shift but as a call for rethinking the larger issues of cultural practice, and saw cultural identity not as something complete and done with but as something that ought to be reconstructed and realized anew with each change in context.

13 Abedin, the most influential artist of 'East Pakistan', founder of the Institute of Fine Art, and the Folk Art Museum, was committed to creating an environment conducive for art. Though he was highly skilled in academic techniques, his work showed a synthesis of a variety of methods. The depiction of rural Bengal in the paintings of Mukul Dey and Ramendranath inspired him. The academic style had lost the enthusiasm of the critics in the thirties and forties. Abedin himself had, from his student days, favoured watercolour and brush over oil paint and canvas (Hossain 2007: 298). At the end of the thirties the academic art schools showed signs of change and influences of modern European movements were being felt. Global eclecticism was a predominant feature of these movements in their early states and many Indian artists who had gone to Europe came back with a new enthusiasm for local arts (Subramanyan 1987: 29-30). 
Figure 1: Zainul Abedin, Famine Sketch-13, brush and ink on paper, 1943.

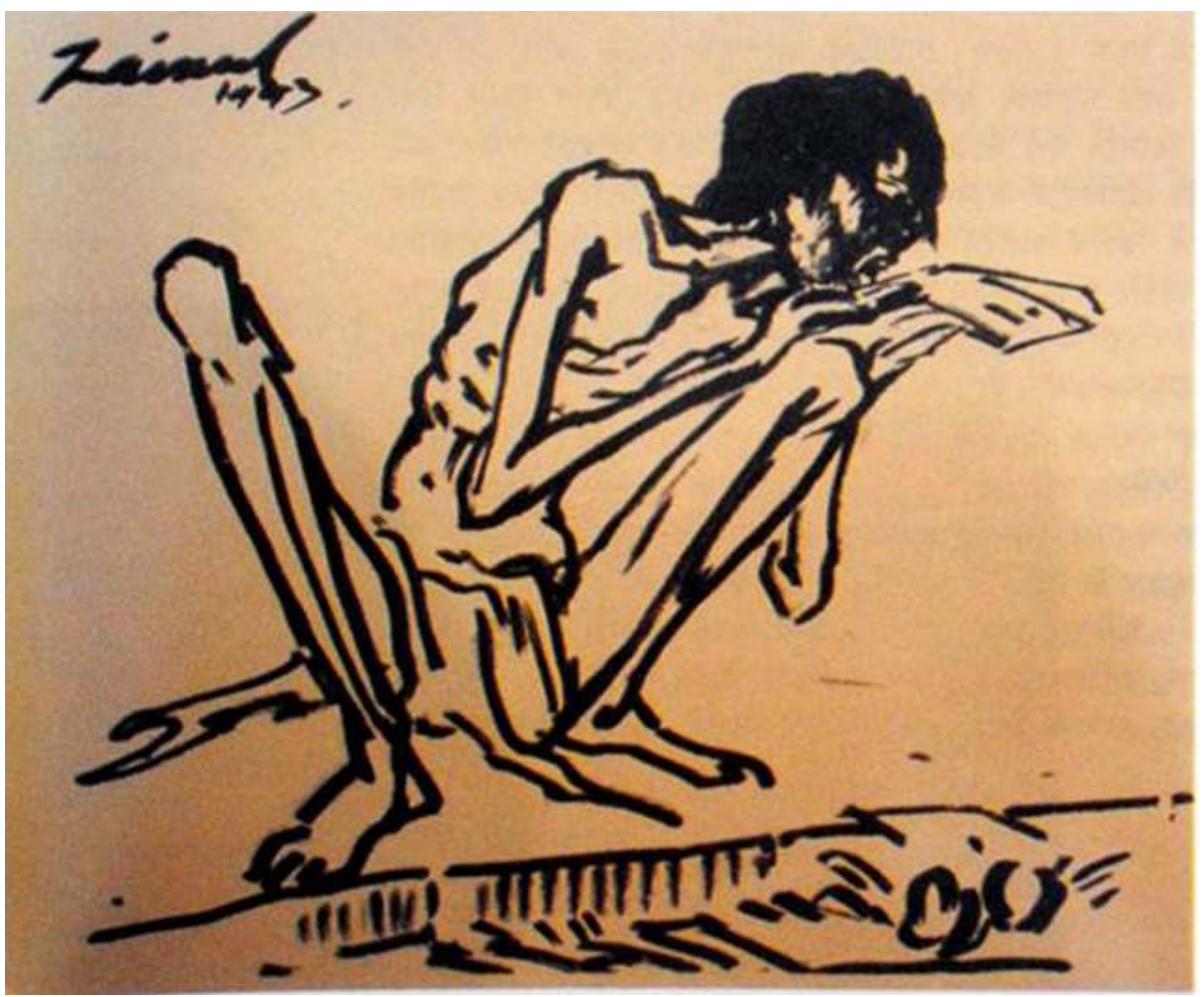

Courtesy of Art and Artists of Bangladesh, multimedia cd published by Rakhal Balak, Dhaka, 2008.

The Famine series of 1943 brought Abedin unprecedented fame and this was probably why some of the characteristics of the series remained permanent features in his work (Figure 1). Lines dominated even when he used colours, and humanity and its struggle for survival became prime subjects (Hossain 2007: 301-302). ${ }^{5}$ In 1951 Abedin went to the Slade School of Fine Art in the UK and visited museums and galleries in Europe. After returning in 1952 he turned to 'folk art' for inspiration. Both global eclecticism and the Language Movement with its associated 'indigenism' probably had a part to play in this. Abedin drew on the simplification of forms, primary colours and ornamental lines of folk art. For example, he appropriated the form of pinched terracotta figures for his paintings such as Painyar Ma (Painya's Mother) of 1953. The tradition that was called into use had its roots in the remote past before the religions in their present forms had evolved, presenting an undivided Bengali identity. It was a subaltern identity, rooted in agrarian Bengal. In 1969 when the struggle for autonomy was at its peak he painted Nabanna (Harvest) in the form of a horizontal scroll, depicting how the life of plenty was destroyed by colonial oppression. Scroll painting, as a method of wandering minstrels narrating tales, is an ancient form in Bengal. The stories are adapted for Hindu and Muslim audiences as they are performed for both. The painters have both Hindu and Muslim names, which they use according to circumstances (Blurton 2006: 21). Abedin thus referred to the religious tolerance of rural Bengal.

Indeginism is also observable in the work of Quamrul Hassan who was a disciple of Gurusaday Dutt' and called himself 'patua' (an artist-minstrel who painted narrative scrolls) to identify himself personally with tradition. He was tremendously inspired by the Bratachari movement, established in 1932 by Gurusaday Dutt with a view to 
consolidating the richness of Bengali heritage against colonialism (Bhattacharya \& Ghosh 2004: 467, Huq 2007: 313). Jamini Roy and to some extent Nandalal's painting series done for the Haripura Congress (1937) inspired Quamrul Hassan. Both were based on folk art. This is why when in the fifties Abedin suggested that he turn to folk art as a source, Jamini Roy and pata (painted scroll) painting were his ideals. His famous Tin Kanya (Three Women) (Figure 2) of 1955 is an example of this ideal (Huq 2007: 313-314). He also borrowed elements of drawing from Picasso's Cubism and the colour perspective of Matisse, thus synthesizing folk and modern artistic languages (Huq 2007: 314-315). Jamini Roy's influence on the Indian art scene is discussed by Subramanyan (1987). 'Primitivism' which found acceptance and became fashionable in Europe, the influence of artefacts from Africa on Picasso and other influential artists drawing influence from folk art forms of Europe and South Asia drew Indian artists to Jamini Roy's stylistic features. This was widespread in the forties in combination with the linear mannerism of post-Cubist Picasso (1987: 34-37). However, the prolific and extremely diverse oeuvre of Hassan branched out in many different directions, defying restrictions of conventions or styles. The adoption of 'primitivism' via folk art may be explained with its acceptance in Europe, and as a solution to the problem of integrating modern language into a national, political context.

Figure 2: Quamrul Hassan, Three Women - 1, oil on masonite board, 1955.

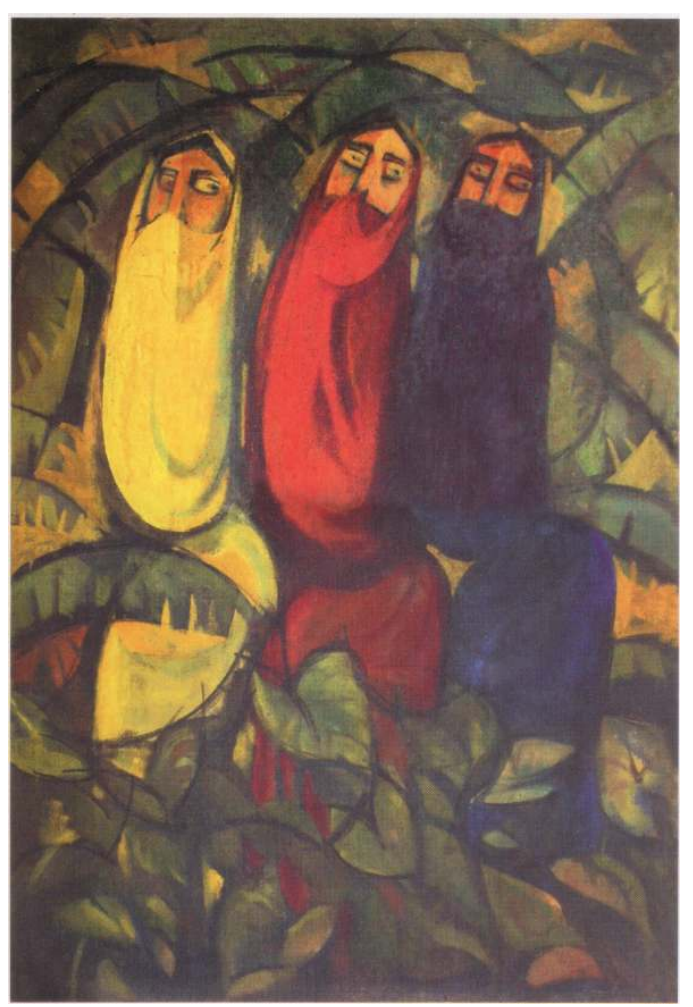

Courtesy of Art and Artists of Bangladesh, multimedia cd published by Rakhal Balak, Dhaka, 2008.

Safiuddin Ahmed adopted simplified abstract formal language after his early representative phase. His work was also transformed after the Language Movement. The people of Bangladesh, boats, water and water borne life appear in his work (Figure 3). Brought up in his ancestral home in Kolkata, his first experience of flood in Bangladesh moved him profoundly. From the mid-fifties the people of Bangladesh appear in 
Safiuddin's drawings showing distinctively Bengali characteristics in contrast to his earlier work which focused on the Santals, an indigenous group of Bengal (Som 2007: 329). His subject included the political struggle of Bengalis and rural life without the stylistic accompaniment characteristic of folk art, but he also focused on rural life and working people in the nationalizing discourse.

Figure 3: Safiuddin Ahmed, Sound of Water, aquatint, soft ground, mezzotint and deep etch, 1985.

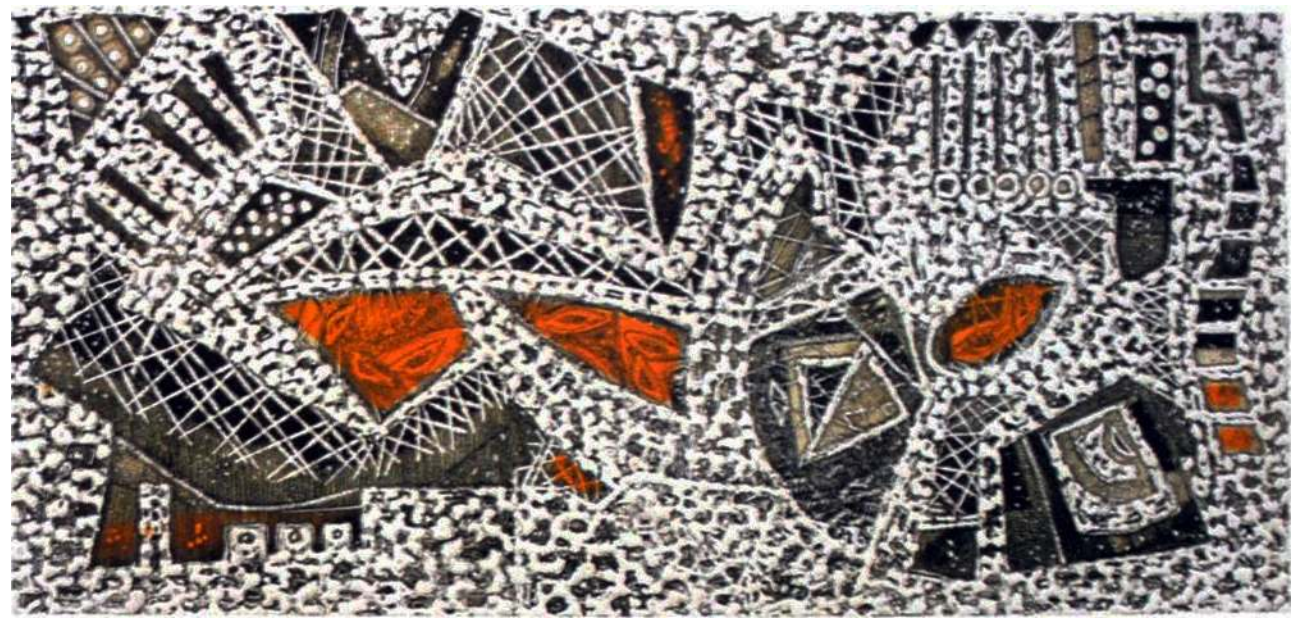

Courtesy of Art and Artists of Bangladesh, multimedia cd published by Rakhal Balak, Dhaka, 2008.

\section{The impact of modernism}

17 The works of the four pioneers of modern art in former East Pakistan preserved links to undivided India and a continuity with it through the turmoil of the emergence of shifting ideas of new national and cultural identities, particularly manifest after the Language Movement. ${ }^{8}$ A break appears with the generation of artists who were the early students of the art institution in Dhaka, quite a number of whom went to Europe, and the USA to study. The newly independent nation made connections with the world and a window to the West suddenly opened for them. They wanted to be part of the international scene of modern art which had been closed to them by the training in the art institute in Dhaka which followed the methods of the Calcutta Art School. Most of them returned to East Pakistan in the second half of the fifties. They ingested Cubism, Abstract Expressionism, Surrealism and a host of other movements of modern Western art; these influences are observable in their work. Semi-abstraction and non-representational abstraction reigned. Concerns about indigenism were washed away in the powerful tide of internationalism (Mansur 2007: 40-41). Most of these artists' works did not reflect an interest in the wider issues of society or analysis of art language. They were individuals, the elitism of their art separating them from societal concerns.

18 Mohammad Kibria (1929-2011), Aminul Islam (1931-2011), Abdur Razzaque (1932-2005), Debdas Chakraborty (1933-2008), Abdul Baset (1935-2002) and many other painters settled for complete abstraction (Figure 4). Hamidur Rahman (1928-1988) and Murtaja Baseer's (b. 1932) paintings veered between the abstract and the figurative. The painter and tapestry artist Rashid Choudhury (1932-1986), the painter and famed book designer Qayyum Chowdhury (b. 1934), and the sculptor Novera Ahmed (b. c1930) tried to unite 
modernism and folk art formally (Mansur 2007: 41, Selim 2007: 134). For many viewers, abstract compositions were synonymous with modern art (Islam 1999: 19). Jahangir states that 'It is a movement by the artists and for the artists. As a movement it does touch the fringe of society, not cuts down deep into it.' Defending modernism, he goes on to say that training in viewing art in society was still rooted to English conventions of visual realism which is why 'conventional spectators' are unable to appreciate modern painting (Jahangir 1974: 2-3).

Figure 4: Mohammad Kibria, Untitled-32, oil on canvas, 2001.

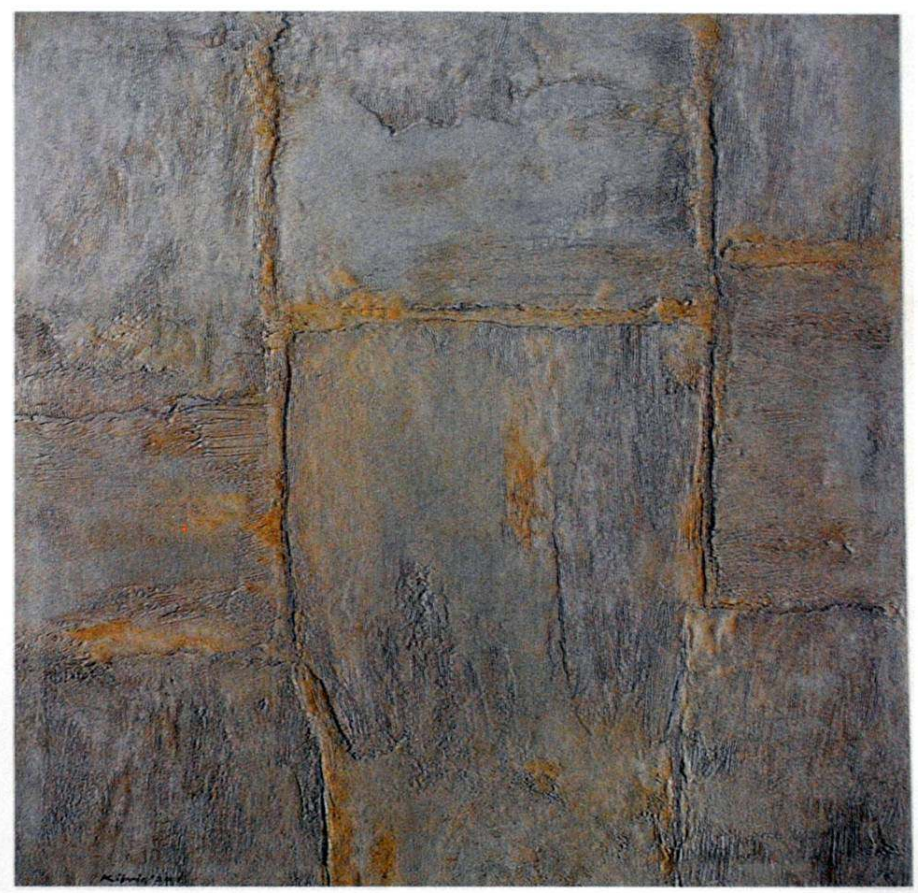

Courtesy of Art and Artists of Bangladesh, multimedia cd published by Rakhal Balak, Dhaka, 2008.

19 According to Islam (1999: 20-21), these painters took to abstraction because it most clearly represented their artistic, emotional, and intellectual understanding of their art. Social compulsion was an added incentive as abstraction seemed consistent with the Islamic aversion to figuration. Azim notes that the rapid spread of Western art movements was part of the colonial legacy where colonial education led to the 'feeling of inferiority' in the colonized nation and it accepted everything the colonizer offered as the best. Its weakness was that it gave precedence to the product over its socio-economic context and completely ignored its philosophical underpinnings. Thus the movement was limited to an external practice of a new form (Azim 2000: 100-101).

These analyses of writers on modernism/abstraction in Bangladesh, and the almost compulsive need to contextualise and explain it, is a continuing discourse. The 'public' and its distance from the work enter the discourse. Modernism/abstraction is a problematic but unavoidable issue and remains unresolved and contested. The notion of the 'universal' language of modernism is seen by some artists of the younger generation as an imported category, not relevant to the context, as Bangladesh itself is not 
economically 'modern'. The somewhat noncommittal remarks of Mansur (2007: 51) hint at this anomaly as he writes:

In the sixties, all leading artists of the fifties, apart from a few, turned to pure abstract style and the practice of art became merely creating an abstract composition on the pictorial surface. Instead of subject and message, proficiency in the medium and cleverness of composition became more of a consideration for the artist.

By implication, abstraction is devoid of conviction and involvement, and accused of mere cleverness of composition. The popular grounding of taste in academic art is almost an apology for its distance from the 'public'.

However, it is notable that in the 1950s many of the intelligentsia and youth gravitated towards progressive, secular politics, and leading artists were active in socio-political movements. As a result, the first stage of many of these artists' productions evinced political commitment, opinion against social inequity and injustice, and compassion for the poor (Mansur 2007: 40). Many artists of this period went on to become important figures in the art world (Mansur 2007: 50). The fifties saw the beginning of art criticism, a sympathetic media, the growth of an art viewing public and professionalism in artists (Islam 1999: 19-20). The importance of this second generation of artists was significant; they brought about new readings of modernism, which altered the art world and its values.

\section{The Liberation War and after}

The birth of Bangladesh brought with it the hope for a secular, democratic, socialist country where Bengali culture would flourish. Art education institutions were established in Chittagong, Rajshahi and Khulna. State patronage of the arts was introduced through the establishment of the Bangladesh Shilpakala Academy. Artists got the opportunity to travel and see art in foreign countries and participate in international exhibitions; the new country built relations with the world in art and education. Contacts grew not only with Western art capitals but with India, Japan and China, bringing further changes in the art world. The Liberation War provided artists with a fitting subject and imbued figurative representation with new vigour. Visual arts during the autocratic rule of the Pakistan army from the late fifties were generally confined to the non-figurative. The war renewed in artists the search for inspiration from Bengali cultural heritage, a new urge to communicate with the people and efforts to incorporate social and political comments in their work. Vitality surged through the art world with a larger number of artists and a greater variety of media. However, abstraction remained a steadfast form although representation did make a revival (Mansur 1999: 31-32, 2007: 53-54).

S. M. Sultan and Shahabuddin are two artists who dealt with the problem of contextualizing Bangladesh in their art, although they did so in different ways. Though Sultan was roughly contemporary with the other pioneers of Bangladeshi modernism, he came to feature on the art scene much later. He travelled widely after Partition in Pakistan, Europe and the USA, finally returning to Narail, his village in Jessore, to live a bohemian life. Sultan selected the people of rural Bengal as his subject but rendered them in a powerfully exaggerated and idealized manner to symbolize the vitality of peasant life (Figure 5). His paintings never include anything produced by modern technology, which, according to him are imported elements. Sultan asserted that the themes of his paintings 
symbolize the energy and labour of Bangladeshi peasants' battle with the soil. He was eloquent about the labour of the peasants on which the region had depended for thousands of years (Akand 2007: 342).

Figure 5: S. M. Sultan, First Plantation, oil on canvas, 1975.

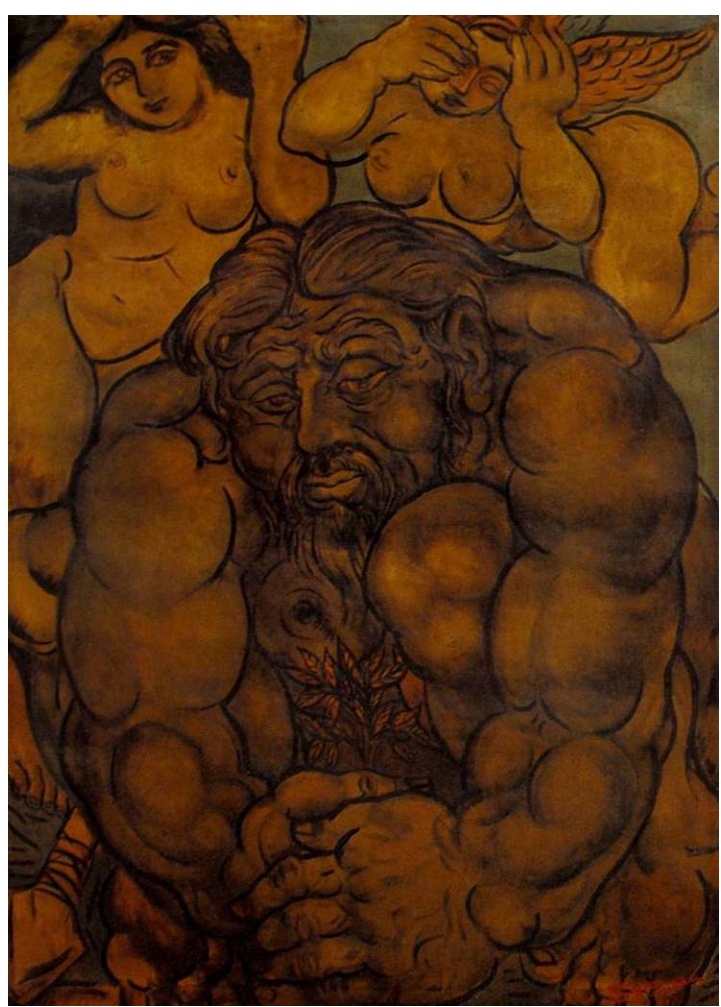

Courtesy of Art and Artists of Bangladesh, multimedia cd published by Rakhal Balak, Dhaka, 2008. and an apparent amateurishness. Recurrent subject matter in the manner of folk art, his compositions and handling of materials give his paintings a proximity to self-taught proficiency which conflicts with the discipline and grammar of art education. He also refers to Sultan's incomplete art education at the Calcutta Art School (2007: 38). Mansur remarks on the lines in Sultan's paintings as being closer to something like urban 'naïve' art as seen in Rickshaw paintings (Akand 2007: 345).

But Sultan was a knowledgeable, well-travelled man and it is difficult to believe that the formal character of his work was anything but dictated by his own choice, not due to a deficiency in art training. This may be another way that Sultan denied importing 'modern technology' into his art, by using a local popular idiom. It is significant that Sultan began to paint in the seventies, after Bangladesh was born. After his return to his village in Narail in 1953, he appeared as an artist in the upper echelons of society of Dhaka in 1975 and in 1976 the Bangladesh Shilpakala Academy organized a solo exhibition of his work. He refuted modernism and 'universal' values in his work as in his life.

Shahabuddin Ahmed (b. 1950) has carved an influential place for himself in the art world of Bangladesh. According to Mitter, he is a remarkable artist produced by the War of Liberation. He joined the armed struggle for independence and the experience deeply affected his work. In 1979 he began to explore the potential of the human form as recalled from his war experience (Figure 6). His male figures in motion effectively capture the 
drama of the war (2001: 219). Shahabuddin's reality is built on Western concerns of anatomy and light and shade, his drawing and colours are realistic and his subject is handled with forceful brushwork. Thus Shahabuddin became 'modern' without denying reality (Mansur 2007: 60). The dramatic, intense and blurred brushwork of his paintings recalls Bacon's style but his work has none of Bacon's horrific connotations. He used the techniques of 'Western' art for a 'national' subject.

Figure 6: Shahabuddin Ahmed, Bangladesh, oil on canvas, 1997.

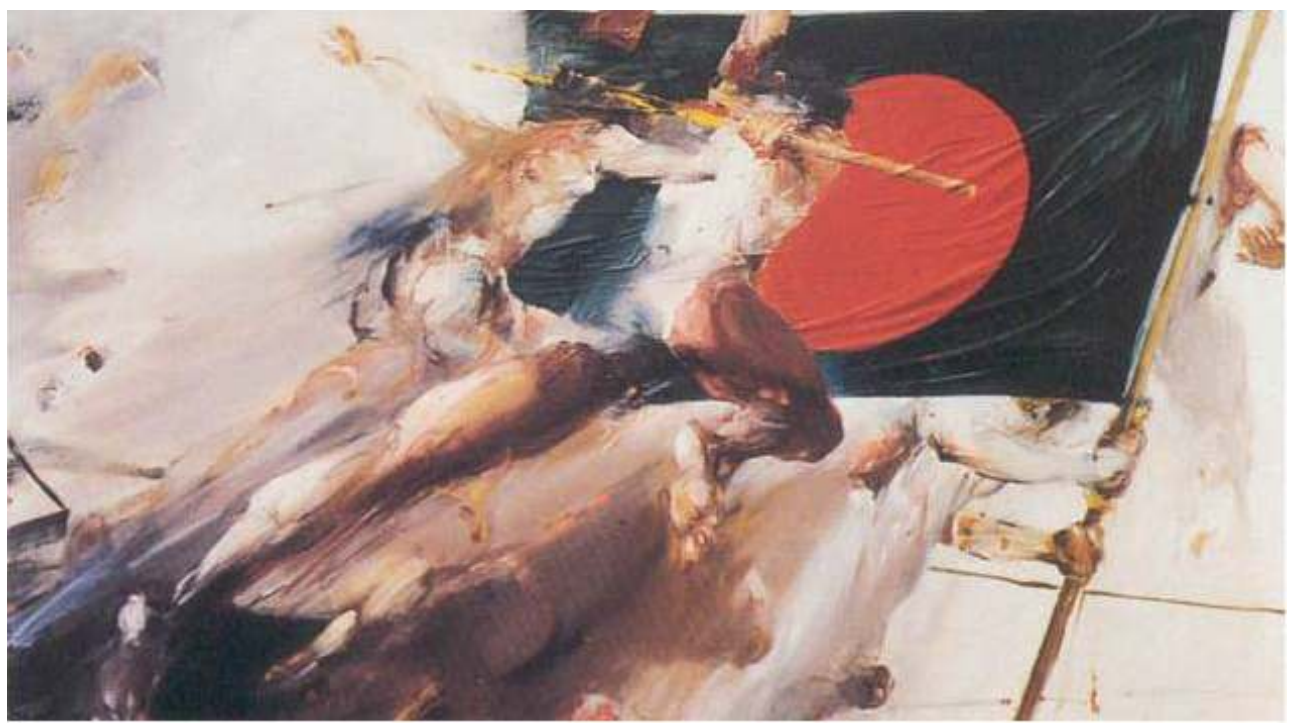

Courtesy of Art and Artists of Bangladesh, multimedia cd published by Rakhal Balak, Dhaka, 2008.

\section{The eighties and after}

The enthusiasm of the early 1970s was dispelled with the political and economic crises that racked the new nation. The killing of Sheikh Mujibur Rahman in 1975 and the prolonged military dictatorship that followed shattered the dreams of liberation; religion again came to feature strongly in politics. In 1975 Major-General Ziaur Rahman, the founder of the Bangladesh Nationalist Party (BNP), assumed power through a coup and made constitutional amendments that facilitated the political rehabilitation of elements that had collaborated with the Pakistani forces and committed crimes against humanity during the War of Liberation, namely the Jama'at-e-Islami, the largest Islamist party in Bangladesh. In 1988 Ershad's pseudo-military government declared Islam the state religion of Bangladesh amidst protests from the intelligentsia, further promoting 'communal politics'. Ershad was forced from power in a massive movement for democracy. The movement, raging through the eighties, had artists actively participating as they had in all political movements.

In the elections of 1991, the BNP came to power. Jama'at leaders became ministers in the two BNP led governments in 1991 and 2001. The current government, led by the Bangladesh Awami League, set up the International Crimes Tribunal to try suspected criminals from the War of Liberation in $1971 .^{9}$ Jama'at leaders have been convicted of crimes by the tribunal. Online activists initiated a movement demanding capital punishment of the offenders in February 2013, to which a large number of artists and art 
students gave their full support. 'Democracy' did not do away with corruption and violence in society, however. The optimism born of struggle, victory and freedom was destroyed. Cynicism and mistrust in institutions began to emerge. NGOs began to flourish, promoting the agenda of foreign donor agencies. Both major political parties influenced by donors such as the World Bank and International Monetary Fund, pursued neo-liberal policies.

Seen against this backdrop, abstraction, always present, regained prominence in art. Dictatorship, repression, corruption and violence also provoked direct political statements as well as satire and innuendoes (Mansur 2007: 61-62). Anti-imperialist and leftist concerns were manifested by some. A larger number of women artists established themselves in the art world showing feminist concerns and new representations of women (Figure 7). But the clear connection that could be discerned between art, politics and tradition through the contestation of 'cultural autonomy' and nation building dispersed after the nation was realized.

Figure 7: Tyeba Begum Lipi, I Wed Myself, video art, double channel projection, 2010.

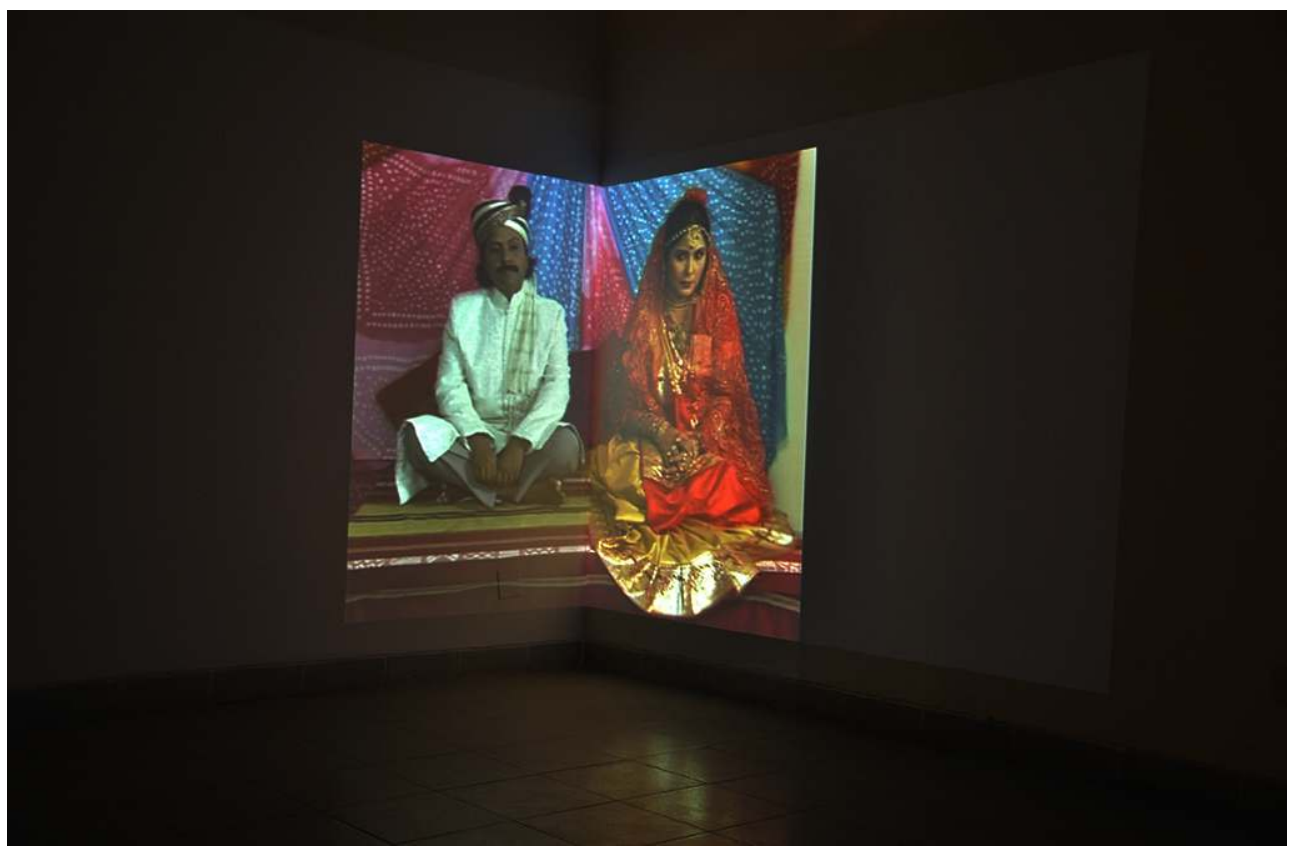

Courtesy of Tyeba Begum Lipi

31 While after partition, artists had appropriated formal elements from folk art, some artists now made a subtler attempt to contextualize tradition. Kapur (2000: 279) writes about modernism in the third world:

Rather than distancing alternative civilizations into objects to be processed by western subjectivity, the nationalist intelligentsia makes some genuinely anxious and responsible appropriations within their own societies. If, then, in the postcolonial ethos all third-world texts appear to be national allegories, all national allegories attempt to restore conceptual wholeness to lost communities through the process of decodifying precisely the canonical images of an inherited tradition.

She goes on to note that appropriated tradition may resemble the eclecticism that the contemporary Western imagination encourages, but it is without the extremity of otherness that produces forms alienated from function and meaning, thus presenting a 
tradition in use in third-world societies as an effective way of politicizing culture (Kapur 2000: 279-280). In Bangladesh it has always been a question of which traditions to identify with and appropriate.

In 1981 the Asian Art Biennale was organized in Dhaka, connecting it to the international art world. Japanese artists introduced trends that transformed the art world of the seventies. With the growth of information technology, the expansion of public media and international trade, artists began to express themselves in a variety of media. The visual influence of conceptual art such as installations, performances, videos and photography, was evident. Globalization and the rapid exchange made possible by the internet made the flow of information instantaneous. Both young and well established artists ventured into this new 'space'. Scattered efforts are seen in the nineties but in the $21^{\text {st }}$ century they become more concerted. In the early years of the $21^{\text {st }}$ century the Asian Art Biennale permitted local artists to participate with projects not limited to two and threedimensional artworks. Foreign travel and networks with foreign organizations fed into this globalizing trend, leading to workshops and residencies with foreign and local artists working together.

Harris (2011: § 1) notes that the term 'globalization' has entered the art world. Though the term denotes forces that have shaped societies and civilizations across the globe, it originated in the 'West' and has achieved dominance beyond Europe and the USA partly through Western colonial and imperial conquest. Has 'globalization' produced some radical homogenization in life that reduces human experiences and values and could this be a common judgement on global art? One of the questions posed is, whether there has developed:

[...] a formulaic style of painting or video-installation produced by artists endlessly crossing continents to exhibit at art biennales, attempting to please the same group of jet-setting ... international curators or New York based dealers now operating out of Beijing or Shanghai? (Harris 2011: § 4).

Kapur (2000: 281) holds that though postmodernism seems to accommodate otherness more than ever in the history of capitalist culture, it goes through a process of such differentiation, by which questions of identity are discarded along with the normative function of culture, and the necessity of choice. Does this 'free' global space make artists conscious of certain entry requirements? According to Thornton (2009: xi), although the global art space of the contemporary world is perhaps more polycentric than ever before, it is still dominated by the art clusters in London, New York, Los Angeles and Berlin.

The way to try and connect to this art world for artists from developing nations like Bangladesh is often dictated by what is in demand in the 'contemporary' art world. ${ }^{10} \mathrm{We}$ have seen several overtures to reach this global art space in the recent past, such as the participation in the Venice Biennales in 2011 and 2013 and the visit of curators from Tate Modern in London in 2011. In 2012 an Art Summit was held in Dhaka where curators from important international institutions were present. The next Dhaka Art Summit is to be held in 2014 with artists participating from across South Asia. ${ }^{11}$ This has as much to do with the Western and global art world's attempt to be polycentric and pluralistic as it is the desire of the Bangladeshi art world to turn global. At its heart is a contradiction between the Western art world's simultaneous economic power and its loss of cultural primacy due to post-modernism (Owens 1994: 591-592). Owens (1994: 592) states:

'[...] the more dispiriting effects of our culture's recent loss of mastery anticipates both the melancholia and the eclecticism that pervade current cultural production- 
not to mention its much touted pluralism. Pluralism, however, reduces us to being an other among others; it is not a recognition, but a reduction to difference to absolute indifference, equivalence, interchangeability [...]. What is at stake, then, is not only the hegemony of Western Culture, but also (our sense of) our identity as a culture.'

Does a similar contradiction apply to the culture and art of 'developing' nations like Bangladesh, where gaining access to a plural world often means reduction to equivalence, interchangeability, becoming part of a homogenous global culture? Kapur suggests that as international art exhibitions become overworked ground for identity made easy, 'primitivism' may be a definitional core of a new internationalism, adopted by third world artists to enter the international art arena. 'Primitivism' is a kind of masquerade, a simulation which may serve to surmount the difficulty of entering the citadels of white culture, and simulation is likely to become a simulacrum, '[...] a copy of that which is nonexistent-what orientalism or primitivism are about: copies of models of that which does not exist' (Kapur 2000: 328). In the context of present Bangladeshi art, 'primitivism' or 'identity' is appropriated more extensively from urban folk or popular art such as rickshaw painting, cinema banners, cheap prints of religious pictures (Figure 8), or even the 'exotic' forms of objects in daily use (Figure 9).

Figure 8: Masum Chisty, Shiva Sitting with My Head, digitally manipulated photograph, 2011.

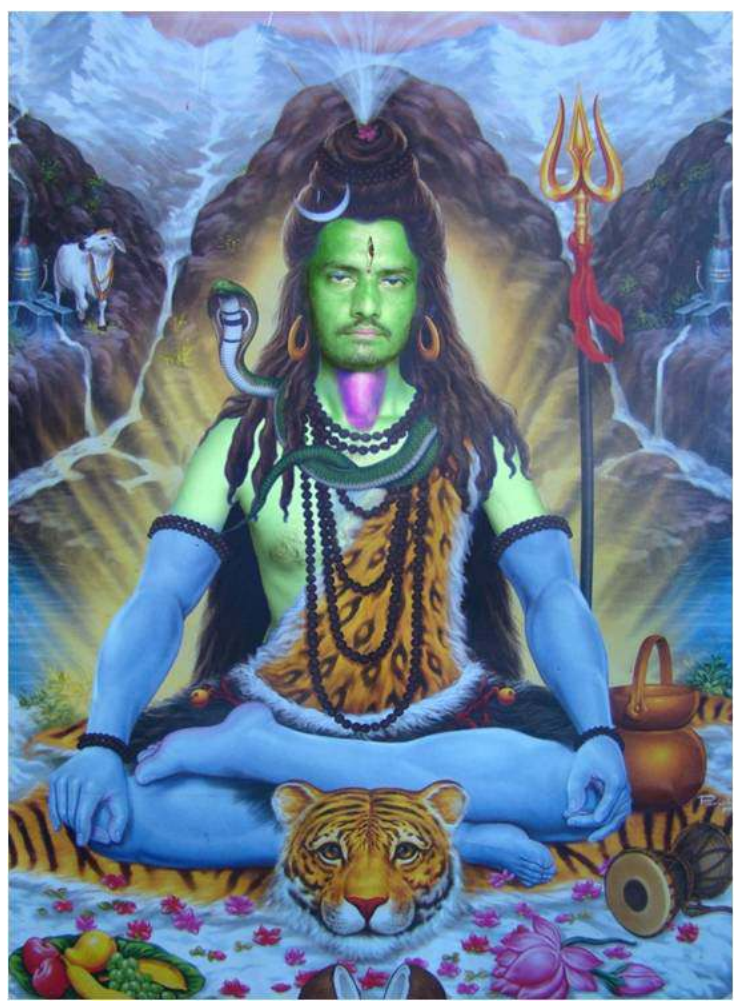

Courtesy of Masum Chisty 


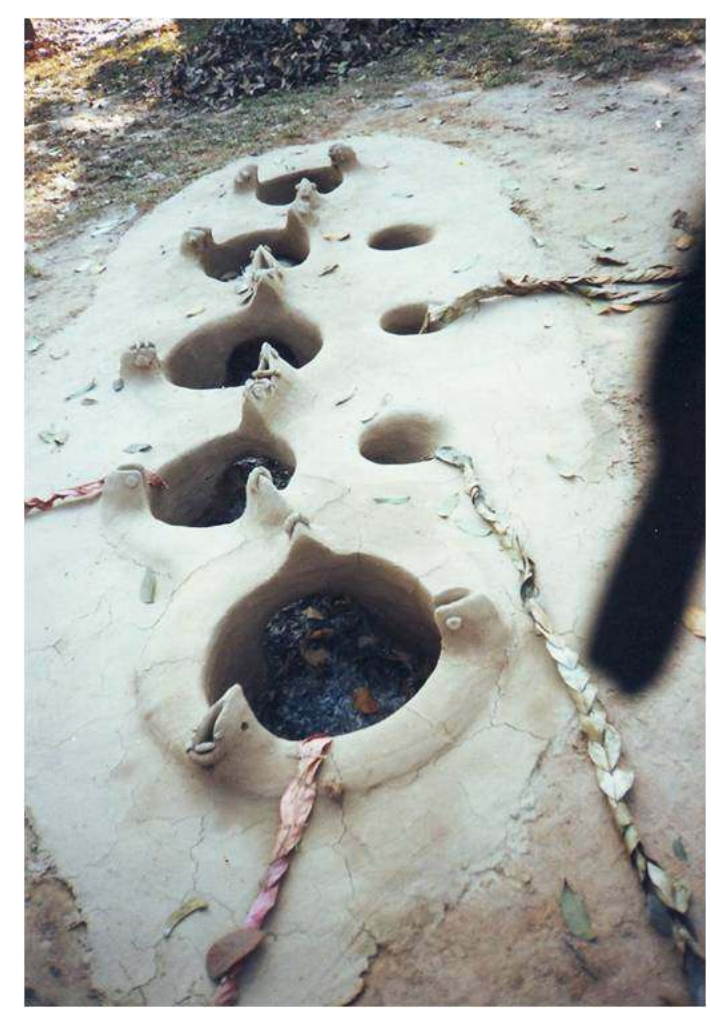

Courtesy of Dhali Al Mamoon

Since the 1990s Dhaka has developed an art market and galleries with the associated circuit of curators, critics, collectors and artists. The state-run Shilpakala Academy for the promotion of arts has steadily lost steam as the free market economy has gained ground. Private entrepreneurs, owners of industries, and multinational companies have come to figure strongly in the local art world, a miniature version of the global one. Art and culture are tools of power and control. The powerful in the world of culture gain access and protection. Akash (2005: 2-4) notes that within the local context of predatory capitalism this access and control is essential to the big loan defaulters who are the largest predatory capitalists of Bangladesh, depending on the patronage of the government and political parties. The art world is spun into the web of these patrons. They spend a pittance of their vast resources to ensure social and political acceptance and voices in the intelligentsia who will raise an outcry if any government dares to challenge them. Their patronage ensures the homage of artists. They hold the strings of power as patrons of the organizations and those who regulate them manipulate the window into the global art world.

\section{Conclusion}

The above discussion is an attempt to look at the art of Bangladesh within the larger context of its history of transformation and fragmentation. It follows historical events, which have created traditions, brought changes to imagined ones, or denied them as well as re-evaluating what they signify. The notion of tradition has played an important role in art; sometimes it has been the catalyst that has brought about a reversal of ideas of 
identity. Traditions, their making, unmaking, and re-making, have been constantly debated throughout the history of the region/nation. The fundamental principles of state policy of Bangladesh have also been revised to a point where they almost seem to backtrack. The fragmentation of identities at different junctures of history has led to the formulation and assumption of new identities and the intelligentsia, of which artists are a part, have played a significant role in this activity. Art has reflected major political changes: the quest for a 'lost' past by the Bengal School; the assumption of Muslim identity after the birth of Pakistan; the reclamation of Bengali heritage in the face of Pakistani hegemony engendered by the Language Movement, with the parallel introduction and assimilation of 'modern' art with its 'universal' values and the encounter with the 'West'; the War of Liberation and the time of optimism when the nation renewed its faith in 'Bengali heritage' and the confusion and disappointments that followed which led to newer engagements with heritage. The developing characteristics of the Bangladeshi art world are studied as it expands towards the global, and signifiers of 'tradition' are hybridized to give Bangladeshi art a distinctive identity in a plural world. This paper explores how and why 'traditions' continue to play an active role in Bangladeshi art, rejuvenating and nourishing the practice of contemporary 'fine' artists trying to make a mark in a globalized world.

\section{BIBLIOGRAPHY}

Akand, Shawon (2007) 'S. M. Sultan', in Lala Rukh Selim (ed.), Cultural Survey of Bangladesh Series-8 Art and Crafts, Dhaka: Asiatic Society of Bangladesh, pp. 338-47.

Akash, Mahbubul Mokaddem (2005) 'Lutera Byabosthar Antarnihita Gatiprabanata' [The Inherent Trends of the Predatory System], Shamajik Bigyan Patrika [Social Science Journal], Dhaka Visvavidyalay [University] Studies, Part D, 1(1), pp. 1-6.

Anisuzzaman (1993) Creativity, Reality and Identity, Dhaka: International Centre for Bengal Studies.

Azim, Faizul (2000) Bangladesher Shilpakalar Adiparba O Ouponibeshik Probhab [The Ancient Period of the Art of Bangladesh and Colonial Influence], Dhaka: Bangla Academy Press.

Bagal, Jogesh Chandra (1966) 'History of the Government College of Art and Craft', Centenary Government College of Art and Craft Calcutta 1864-1964, Calcutta: Government College of Art and Craft, pp. 1-58.

Barrett, Douglas; Gray, Basil (1978) Indian Painting, New York: Rizzoli International Publications, Inc., [1963].

Bhattacharya, Asok (1994) Banglar Chitrakala [Painting of Bengal], Kolkata: Paschimbanga Bangla Academy.

Bhattacharya, Mihir; Ghosh, Dipankar (eds.) (2004) Bangiya Shilpa Parichay [Introduction to Bengali Art], Kolkata: Lokosangskriti o Adibashi Sangskriti Kendra, Tathya o Sangskriti Bibhag, Pashchimbanga Sarkar [Centre for Folk and Indigenous Culture, Information and Culture Department, Government of West Bengal]. 
Blurton, T. Richard (2006) Bengali Myths, London: The British Museum Press.

Dehejia, Vidya (2008) Indian Art, London: Phaidon Press Limited, [1997].

Eaton, Richard M. (1984) 'Islam in Bengal', in George Michell (ed.), The Islamic Heritage of Bengal, Paris: United Nations Educational, Scientific and Cultural Organization, pp. 23-36.

Ghosh, Mrinal (2005) Bingsha Shatake Bharater Chitrakala: Adhunikatar Bibartan [The Painting of India in the Twentieth Century: The Evolution of Modernism], Kolkata: Pratikshan.

Guha-Thakurta, Tapati (2007). Monuments, Objects, Histories: Institutions of Art in Colonial and Postcolonial India, New Delhi: Permanent Black, [2004].

Guha-Thakurta, Tapati (1992) The Making of a New 'Indian' Art: Artists, Aesthetics and Nationalism in Bengal, c. 1850-1920, Cambridge: Cambridge University Press.

Gupta, Akhil; Ferguson, James (1992) ‘Beyond “Culture”: Space, Identity, and the Politics of Difference’ Cultural Anthropology, 7(1), pp. 6-23.

Haque, Zulekha (1980) Terracotta Decorations of Late Mediaeval Bengal: Portrayal of a Society, Dhaka: Asiatic Society of Bangladesh.

Harris, Jonathan (2011) 'Introduction', in Jonathan Harris (ed.), Globalization and Contemporary Art, West Sussex: Wiley-Blackwell, pp. 1-16.

Hossain, Nisar (2007) 'Zainul Abedin', in Lala Rukh Selim (ed.), Cultural Survey of Bangladesh Series-8: Art and Crafts, Dhaka: Asiatic Society of Bangladesh, pp. 291-308.

Huq, Syed Azizul (2007) 'Quamrul Hassan', in Lala Rukh Selim (ed.), Cultural Survey of Bangladesh Series-8: Art and Crafts, Dhaka: Asiatic Society of Bangladesh, pp. 309-23.

Islam, Syed Manzoorul (1999) 'From Bengal School to Bangladeshi Art', in Syed Manzoorul Islam \& Azra J. Ahmed (eds.), Arts \& the Islamic World, No 34-Autumn, London: Arts \& The Islamic World (UK) Limited, pp. 7-22.

Jahangir, Burhanuddin Khan (1974) Contemporary Painters: Bangladesh, Dhaka: Bangla Academy.

Kapur, Geeta (2000) When Was Modernism: Essays in Contemporary Cultural Practice in India, New Delhi: Tulika Books.

Kumar, R. Siva (2002) 'Culture Specificity, Art Language and the Practice of Modernism: An Indian Perspective', in Pratapaditya Pal (ed.), Marg A Magazine of the Arts, 53(3), pp. 8-19.

Mansur, Abul (1999) 'The Seventies and Beyond: Encountering New Realities', in Syed Manzoorul Islam \& Azra J. Ahmed (eds.) (1999), Arts \& the Islamic World, No 34-Autumn, London: Arts \& The Islamic World (UK) Limited, pp. 31-8.

Mansur, Abul (2007) 'Painting: c. Colonial Period to the Present', in Lala Rukh Selim (ed.), Cultural Survey of Bangladesh Series-8 Art and Crafts, Dhaka: Asiatic Society of Bangladesh, pp. 23-73.

Mitter, Partha (1994) Art and Nationalism in Colonial India 1850-1922: Occidental Orientations, Cambridge: Cambridge University Press.

Mitter, Partha (2001) Indian Art, Oxford: Oxford University Press.

Narzary, Janak Jhankar (1993) 'Modern Indian Sculpture: a Background up to 1950', in Janak Jhankar Narzary (ed.), Nandan, Vol. XIII, Santiniketan: Department of Art History, Kala-Bhavana, Visva-Bharati, pp. 44-54. 
Owens, Craig (1994) 'The Discourse of Others: Feminists and Postmodernism', in Stephen David Ross (ed.) (1984), Art and its Significance: an Anthology of Aesthetic Theory, New York: State University of New York, pp. 591-98.

Rashid, Harun-or- (2007) 'Stages of State Formulation: c. Colonial Period', in Emajuddin Ahmed \& Harun-or-Rashid (eds.), Cultural Survey of Bangladesh Series-3: State and Culture, Dhaka: Asiatic Society of Bangladesh, pp. 65-80.

Roy, Niharranjan (1993) Bangalir Itihas: Adiparba [A History of the Bengali People: Early Period], Calcutta: Dey's Publishing, [1959].

Rushdie, Salman (1991) Imaginary Homelands: Essays and Criticism 1981-1991, New Delhi: Penguin Books India in association with Granta Books, [1981].

Selim, Lala Rukh (1998) ‘50 Years of the Fine Art Institute’, Art: A Quarterly Journal, 4(2), pp. 6-13.

Selim, Lala Rukh (2007) 'Sculpture: c. Colonial to Contemporary', in Lala Rukh Selim (ed.), Cultural Survey of Bangladesh Series-8: Art and Crafts, Dhaka: Asiatic Society of Bangladesh, pp. 120-40.

Som, Sovon (2007) 'Safiuddin Ahmed', in Lala Rukh Selim (ed.), Cultural Survey of Bangladesh Series-8 Art and Crafts, Dhaka: Asiatic Society of Bangladesh, pp. 324-37.

Subramanyan, K. G. (1987) The Living Tradition: Perspectives on Modern Indian Art, Calcutta: Seagull Books.

Thompson, Tok (2006) 'Tradition through Modernity: Postmodernism and the Nation-State in Folklore Scholarship', Cultural Analysis, http://www.thefreelibrary.com/Tradition+through +Modernity\%3A+Postmodernism+and+the+Nation-State+in...-a0171539690, accessed 15 June 2013. Thornton, Sarah (2009) Seven Days in the Art World, London: Granta Books, [2008]. Topsfield, Andrew (1979) 'Painting', in Robert Skelton \& Mark Francis (eds.), Arts of Bengal: The Heritage of Bangladesh and Eastern India, London: Whitechapel Art Gallery, pp. 34-8.

Umar, Badruddin (1967) Sanskritir Sankat [Crisis of Culture], Dhaka: Abu Nahid.

\section{NOTES}

1. Here traditional art is used to denote old cultural art forms that persist in a changing society (Subramanyan 1987: Introduction § 9)

2. The emperors of the Mughal Empire (1526-1757), Akbar (1556-1605) and Jahangir (1605-1627) were patrons of painting and developed a refined style of miniature painting blending Persian, Indian and European elements. The provincial style of miniatures was developed in the seventeenth century outside the Mughal court but within the sphere of its political control, as in Murshidabad of Bengal. Pahari painting emerged in the eighteenth century with the dismemberment of the Mughal Empire. The Hill States termed pahari (of the hills) were separate regional kingdoms ruled by Rajputs lying north of Rajasthan in the foothills of the Himalayas, including Kangra, Chamba, Basohli, Guler, Kulu and Jammu, developed identifiable styles of painting (Barret \& Gray 1978: 11-16, Mitter 2001: 143-154, Topsfield 1979: 35, Dehejia 2008: 299-351).

3. The independent sultans of Bengal (1342) broke away from the Muslim rulers in far off Delhi and continued to rule until the Mughal conquest of eastern India by Akbar (1576). This period saw the consolidation of Islam in the region, the development of distinctive brick architecture, and Bengali literature began to be established patronized by sultanate rulers, as opposed to 
Sanskrit which was patronized by the last Hindu dynasties of Bengal (Blurton 2006: 16).

According to Eaton (1984: 27-28):

It was during this period [...] that a uniquely Bengali Muslim culture flourished. Put more precisely, the independent sultans of this period permitted Bengali culture [... ] to flourish and combine with styles and influences drawn from north India, Central Asia, or the Middle East.

The Muslim court also encouraged Vaishnavism which was opposed by the caste of Shakta Brahmans who emphasized Sanskrit over Bengali and high-caste exclusiveness over nonBrahmin inclusiveness. It patronized Vaishnava literature and also employed Vaishnavas in positions of trust in the administration (Eaton 1984: 29).

4. Abdul Huq (1918-1997), journalist and writer, wrote essays on society and politics and analyses of the language issue.

5. The Famine had a profound influence on the art of Bengal. It created a rich stream of art practice based on social commitment. Abedin, Chittaprasad Bhattacharya, Debabrata Mukhopadhyaya and Somnath Hore made immense contributions to this trend.

6. The contentious term 'folk art' in this context denotes forms of art that developed in preindustrial times and were (and are) still actively practised in the subcontinent, some nonprofessionally by women in their households, or ritual arts practised by priests and medicine men. Others are professional forms produced for the needs of people by craftsmen such as potters, weavers and metal smiths (Subramanyan 1987: 57).

7. Gurusaday Dutt was a Bengali official in the imperial bureaucracy whose campaigns created an intense interest in the village arts among the urban elite (Mitter 2001: 163).

8. They shared common educational backgrounds, history, resistance to British colonial rule and a general cultural milieu with their contemporaries in West Bengal. Calcutta Art School, of which they were all students, provided them with basic training and ideas of art. By then, with Mukul Chandra Dey as Principal from 1928 to 1943 the school had been transformed. He was in close contact with Rabindranath Tagore and was a student of Abanindranath. He travelled and studied in the USA and UK and was acquainted with western art movements. He did not believe in compartmentalizing art into Western and Eastern. Ramendranath Chakravorty, a student of Nandalal at Kala Bhavana, Visva Bharati infused new life into the Indian painting department. He encouraged students to depict original themes from everyday life. This reflected a changing national outlook. The earlier themes in Havell and Abanindranath's times were from ancient history, myth and literature followed by copying Rajput and Mughal miniatures in the twenties. Mukul Dey also organized painting exhibitions of Jamini Roy's work celebrating pata painting, Rabindranath and noted foreign painters of the East and West (Bagal 1966: 44-50).

9. See Zeitlyn's contributions in this volume.

10. The author's observations are drawn from attending/observing Biennales and other art events.

11. Author's discussion with one of the organizers of the Summit, Dhaka, 19 August 2013.

\section{ABSTRACTS}

This paper addresses the issue of configurations of Bangladeshi cultural identity as manifested in the art of Bangladesh. It reviews the politics of identity and the concomitant changes in artistic forms during the struggle for independence from Britain and the liberation of Bangladesh from 
Pakistan. It focuses on artistic practices in post-liberation Bangladesh and the evolving current scene, influenced by currents of globalization, holding new challenges for artists. The emergence of Bangladesh as a nation state, and the process of its emergence, has been instrumental in the direction of art in Bangladesh. Configurations of identity and their changing perceptions, vis-àvis the intelligentsia, have played a major role in fashioning its form. This paper analyzes the multiple readings and roles of 'tradition' in the construction of identity and how 'folk' and 'popular' arts of Bengal have continued to provide a rich source for 'fine' artists to draw upon.

INDEX

Keywords: Bangladesh, art, politics, identity, globalisation.

\section{AUTHOR}

\section{LALA RUKH SELIM}

Professor of Sculpture, Department of Sculpture, University of Dhaka, Bangladesh 